IZA DP No. 4823

Wages and Immigrant Occupational Composition in Sweden

Jorgen Hansen

Roger Wahlberg

Sharif Faisal

March 2010 


\title{
Wages and Immigrant Occupational Composition in Sweden
}

\author{
Jorgen Hansen \\ Concordia University, \\ CIREQ, CIRANO and IZA \\ Roger Wahlberg \\ University of Gothenburg \\ and IZA \\ Sharif Faisal \\ Concordia University
}

\author{
Discussion Paper No. 4823 \\ March 2010 \\ IZA \\ P.O. Box 7240 \\ 53072 Bonn \\ Germany \\ Phone: +49-228-3894-0 \\ Fax: +49-228-3894-180 \\ E-mail: iza@iza.org
}

\begin{abstract}
Any opinions expressed here are those of the author(s) and not those of IZA. Research published in this series may include views on policy, but the institute itself takes no institutional policy positions.

The Institute for the Study of Labor (IZA) in Bonn is a local and virtual international research center and a place of communication between science, politics and business. IZA is an independent nonprofit organization supported by Deutsche Post Foundation. The center is associated with the University of Bonn and offers a stimulating research environment through its international network, workshops and conferences, data service, project support, research visits and doctoral program. IZA engages in (i) original and internationally competitive research in all fields of labor economics, (ii) development of policy concepts, and (iii) dissemination of research results and concepts to the interested public.
\end{abstract}

IZA Discussion Papers often represent preliminary work and are circulated to encourage discussion. Citation of such a paper should account for its provisional character. A revised version may be available directly from the author. 
IZA Discussion Paper No. 4823

March 2010

\begin{abstract}
Wages and Immigrant Occupational Composition in Sweden*

This paper examines the relationship between immigrant occupational composition and wages in Sweden. Effects of changes in proportion of immigrant workers in different occupations on the wage levels of both natives and immigrants are estimated. Our results suggest that increases in immigrant density have only small effects on wages and that the negative relationship between wages and the proportion of immigrant workers in an occupation, observed in data, is almost entirely accounted for by measured and unmeasured worker skills. These results suggest that wage differences across occupations with different densities of immigrants are mainly due to quality sorting and to a lesser extent due to the existence of discrimination.
\end{abstract}

JEL Classification: J31, J71

Keywords: immigrants, refugees, occupational composition, quality sorting, wages

Corresponding author:

Jorgen Hansen

Concordia University

Department of Economics

1455 de Maisonneuve Blvd. W.

Montreal, Quebec, H3G 1M8

Canada

E-mail: Jorgen.Hansen@concordia.ca

\footnotetext{
* Financial support from the Royal Swedish Academy of Sciences is gratefully acknowledged.
} 


\section{Introduction}

There is growing recognition that migration is one of the defining global issues of our time and an essential component of the economic life of every State. Today, 214 million people, or 3.1 percent of the world's population, live outside their country of birth. ${ }^{1}$ Rapid population growth combined with lack of economic opportunities induce people from developing countries to move elsewhere, and a declining and ageing population pressures developed countries to accept a high number of migrants, paving the way for an even greater mobility of people in years to come.

The existing migration literature primarily focuses on the assimilation of the migrant workers in the host country labour market, mainly through their earnings and wage growth (Chiswick, 1978, 1980; Borjas, 1985, 1989; Baker and Benjamin, 1994; Bloom, Grenier, and Gunderson, 1995; Edin et al., 2000; Ekberg, 1990, 1994). The type of jobs that the migrant workers obtain, however, is a crucial issue that influences their performance in the destination country. Indeed, it is often argued that immigrant and native workers do not have equal access to 'good' jobs. This form of discrimination against immigrants has also been well documented (Piore, 1979; Hammar, 1985; Zimmermann, 1994; Green, 1995). One consequence of this form of discrimination is the different sectoral distribution of native and immigrant workers.

In the face of changing landscape of the labour market in host countries, the negative relationship between wages and the immigrant composition of jobs, however, has received little attention. Using a unique longitudinal data set, this paper studies the

\footnotetext{
${ }^{1}$ UN Department of Economic and Social Affairs
} 
negative relationship between wages and the immigrant composition of occupations in Sweden, by contrasting the wages of workers in jobs with different immigrant density.

The framework we adopt in this paper is similar to that used in Hirsch and Schumacher (1992) and Hirsch and Macpherson (2004). Focusing on racial composition and wages in the United States, Hirsch and Schumacher (1992) found that wages for white and black workers were considerably lower in industry-occupation-region groups with a high share of black workers due to quality sorting. This analysis was extended by Hirsch and Macpherson (2004) using racial density as an index of unobserved skills. Their result was consistent with the quality sorting explanation, rather than with existence of discrimination.

In this study, we apply the quality sorting approach of Hirsch and Macpherson (2004) to examine why wages of workers, immigrant and native alike, are considerably lower in occupations with high concentration of immigrants in Sweden.

We use a unique Swedish longitudinal data set, Longitudinal Individual Data (LINDA), consisting of a large panel of representative individuals and their household members from 1968 to 2007. LINDA contains information regarding individuals' occupations at a three-digit level from 109 occupations. Having access to detailed occupational information is essential for a study like this. Another unique feature of this data set is having access to workers' contracted wages and thus avoiding measurement error in wages. Due to the longitudinal structure of LINDA, we create an unbalanced sample, in which we require individuals to be observed for at least two periods out of the possible nine. $^{2}$

\footnotetext{
${ }^{2}$ Although certain information in LINDA is available for the period 1968 to 2007, detailed occupational data is only available after 1998. Hence, in this paper we will utilize data covering the period 1999 to 2007.
} 
A potential problem of studying the relationship between wages and occupational features is that occupational attainment is endogenous. To control for this, we take advantage of the longitudinal nature of the data and utilize a fixed effects regression model. Our results indicate that estimates are sensitive to the choice of estimation strategy across demographic groups. In particular, the effect of immigration-based worker density on wages is reduced sharply when endogeneity of occupational attainment is controlled. An increase in immigrant density penalizes refugee workers the most, with each 10 percent increase in the proportion of immigrants in the workplace being associated with a 0.16 percent reduction in wages. The estimated wage effects are similar when refugee density of occupations is considered instead. Furthermore, when we investigate the relationship between wages and new immigrant composition or new refugee immigrant composition of occupations, we find that the wage penalties are even smaller.

Overall, our results suggest that the negative relationship between wages and the proportion of immigrant workers in an occupation, observed in data, is almost entirely accounted for by measured and unmeasured worker skills. Consequently, these findings suggest that wage differences across occupations with different densities of immigrants are mainly due to quality sorting and to a lesser extent due to the existence of discrimination.

We begin the paper with a discussion of theories on immigration-based occupational segregation in Section 2. We outline our econometric strategy for estimating the effect of immigrant density on wages in Section 3. The following section discusses the data and its relevant features. We next report the detailed results of our study. In a 
final section of the paper, we summarise our findings and conclude with possible policy implications.

\section{Wages and occupational segregation}

Negative relationship between wages and the immigrant composition of occupations may be rationalised by one, or a combination, of the following alternative explanations:

- Employers may choose not to hire immigrant workers because of their aversion towards such workers;

- Employers may not be able to correctly assess immigrants' skill levels and may, therefore, assume that the proportion of high skilled workers is lower among immigrants than natives; or

- The proportion of immigrant workers with high skills is actually less than that of native workers.

Extending the simple quality sorting model presented in Hirsch and Macpherson (2004) illustrates the idea. Similar to Hirsch and Macpherson (2004), assume that there are two types of workers: low skilled and high skilled. Assume further that their marginal revenue products are $L$ and $H$, respectively. Finally, $P_{I}$ and $P_{N}$ are the proportions of immigrant and native workers with productivity $\mathrm{H}$, while $\left(1-P_{I}\right)$ and $\left(1-P_{N}\right)$ are the proportions of immigrant and native workers with productivity $L$. However, because the actual skill levels of immigrant workers are unknown to employers (or because they are averse to hiring such workers), the proportion of high skilled immigrant workers, $P_{I}$, is not observed. Instead, $P_{I}^{*}=P_{I}-\varepsilon$ is used, where $\varepsilon$ reflects the extent of uncertainty 
about immigrants' skill levels. The average productivities or wages of immigrant and native workers, $V_{I}$ and $V_{N}$, respectively, are:

$$
\begin{aligned}
& V_{I}=P_{I}^{*} H+\left(1-P_{I}^{*}\right) L \\
& V_{N}=P_{N} H+\left(1-P_{N}\right) L
\end{aligned}
$$

while the average productivity across all workers is:

$$
V=I M M D * V_{I}+(1-I M M D) * V_{N}
$$

where $I M M D$ is the proportion of immigrants in the workplace.

Taking the derivative of $V$ with respect to IMMD illustrates how wages may change as IMMD changes:

$$
\frac{\partial V}{\partial I M M D}=\left[\left(P_{I}-\varepsilon\right)-P_{N}\right] *(H-L)
$$

Assuming that $H$ workers are always more productive than $L$ workers, there are two ways the concentration of immigrants may negatively affect wages: First, in the absence of uncertainty of immigrants' skills $(\varepsilon=0)$, the average wage decreases as the concentration of immigrants in the workplace increases if $P_{N}>P_{I}$. This may be the case if a great deal of host-country specific human capital is required in the job, something immigrants have less of than natives (particularly upon arrival); Second, even if $P_{I}=P_{N}$ a negative relationship between wages and IMMD may arise if $\varepsilon>0$. In this case, high skilled immigrant workers may be forced to work in low-skilled jobs receiving wages below their productivity levels, wages that are lower than those received by similarly skilled native workers.

The above analysis may also be used to illustrate how immigrants' wages change with time spent in the host country. Let $t$ denote time since arrival in the host country for 
an immigrant and define $P_{I t}^{*}=P_{I t}-\varepsilon_{t}$. Thus, the perceived proportion of skilled immigrant workers changes over time, both because immigrants acquire host-country specific skills that are valued in the labour market (so that $P_{I t}$ increase) and because employers learn about the true skill distribution of immigrants (so that $\varepsilon_{t}$ decrease). This also suggests that the effect of $I M M D$ on wages depends on time since arrival. If $I M M D_{A}$ is a measure of the concentration of recent immigrants and $I M M D_{B}$ is a measure of the concentration of immigrants that have spent some time in the host country, then:

$$
\left|\frac{\partial V}{\partial I M M D_{A}}\right|>\left|\frac{\partial V}{\partial I M M D_{B}}\right|
$$

With access to longitudinal data, it is possible to learn about the existence and, if present, the extent of discrimination against immigrants in the labour market. For instance, if the empirical results indicate that $I M M D$ has no effect on wages after controlling for observed and unobserved worker attributes, it must be the case that $\varepsilon=0$ (no discrimination or uncertainty) and $P_{I}=P_{N}$ (no difference in skill distributions between immigrants and natives). On the other hand, if IMMD has a significant effect on wages, either $\varepsilon>0$ or $P_{N}>P_{I}$. However, by assuming that access to longitudinal data enables us to fully control for differences in skill distributions through a fixed-effects model, a significant effect of IMMD must arise because $\varepsilon>0$.

We may also learn about changes in immigrant wages over time from longitudinal data. In particular, if the effect of IMMD depends on the immigrant cohort being used to define $I M M D$ and if the effect is significant for recent immigrants but not for older immigrant cohorts, this would indicate that immigrants' earnings increase because their 
skill levels increase or because employers learn about their true skill levels. Unless preference discrimination is a time-varying phenomenon, such a finding would not be consistent with the hypothesis that employers discriminate against immigrants.

\section{Empirical specification}

A potential problem in exploring the relationship between wages and the concentration of immigrants in an occupation is that occupational attainment is endogenous. There are at least two reasons for why this is the case: First, if immigrants and natives with higher unmeasured skills (captured by the error term in the wage equation) are more likely to be sorted into natives' jobs and those with lower skills into immigrants' jobs, then the exogeneity assumption will obviously be violated (note that this kind of sorting may result from employer discrimination); Second, the error term may also capture unobserved differences in preference among workers, which implies that the assumption of no correlation between the density of immigrants in an occupation and the error term can be violated.

To avoid the potential problem with endogeneity, we apply a fixed-effects estimator. The advantage with such a procedure is that it differences out any timeinvariant unobserved (and observed) variables. Under the assumption that only the timeinvariant portion of the error term is correlated with proportion of immigrants in a given occupation, this procedure yields unbiased estimates of the effect of proportion of immigrants on wages.

Another potential problem is that estimates of the parameter of the proportion of immigrants may be biased if the proportion of immigrants in a given occupation is 
correlated with occupational-level wage determinants not included in the wage equation. Therefore, following Baker and Fortin (2001) and Hirsch Macpherson (2004), we not only include $X_{i}$ measured at the individual level, but also the means of $X_{i}$ at the occupational level, to control for omitted occupational wage determinants.

Specifically, the relationship between wages and immigrant composition is estimated by:

$$
\ln w_{i t}=\sum \beta_{k} \cdot X_{i k t}+\sum \alpha_{j} \cdot Z_{i j t}+\delta \cdot I M M D_{i t}+\varepsilon_{i t}
$$

where $\ln w_{i t}$ is the $\log$ of hourly wage for individual $i$ in year $t, X_{k}$ consist of $X_{l}=1$ and $k-1$ variables measuring personal characteristics measured at the individual level, $\beta_{k}$ includes a constant and $k-1$ coefficients corresponding to variables in $X, Z_{j}$ includes occupation means of the $X^{\prime} s$ with $\alpha_{j}$ being the corresponding coefficients, IMMD is the proportion of immigrants to total employment in the worker's detailed occupation, $\delta$ is the parameter on $I M M D$, measuring the elasticity of wages with respect to Immigrant Density.

The error structure is assumed to be:

$$
\varepsilon_{i t}=\eta_{i}+\nu_{i t}
$$

where $\nu_{i t}$ are independently normally distributed with mean zero and variance $\sigma_{\nu}^{2}$, and $\eta_{i}$ are the individual-specific fixed-effects. It is assumed that $\eta_{i}$ are independent of $\nu_{i t}$.

\section{Data}

The data used in the empirical analysis is drawn from the Swedish Longitudinal Individual Data (LINDA), supplied by Statistics Sweden. LINDA consists of a large 
panel of representative individuals and their household members from 1968 to 2007. The first wave took place in 1994 when 300,000 individuals, which corresponds to about 3 percent of the Swedish population, were drawn. These individuals were followed back to 1968 but also forward, in order to create a panel that is updated annually. Each wave is cross section representative of the population, since new individuals replace individuals who leave (e.g. divorce, death, or emigration). For more information about LINDA, see Edin and Fredriksson (2000).

The sample used in this study comes from the 1999 to the 2007 waves of LINDA. We use these waves from LINDA since information regarding individuals' occupations at a three-digit level is only available from 1999 and onwards.

Another notable feature of this data set is the possibility of matching individual records with wage information provided by employers. Employers report monthly earnings to Statistics Sweden, expressed in full-time equivalents which gives the amount an individual would have earned if working full-time. To obtain hourly wage rates, the monthly earnings are divided by 165 . The hourly wage rates obtained in this fashion correspond to the workers' contracted wages and are less likely to suffer from measurement errors, which are common in self-reported wages.

We limit the analysis to males aged 18 to 64, excluding self-employed workers, students, and individuals with missing values on observed characteristics. After these selections we constructed an unbalanced sample, in which we required persons to be observed for at least two consecutive periods out of the possible nine.

After the selections, the sample consists of 61,540 Swedish born males (and 381,470 observations for these males), and of 6,883 male immigrants (36,668 
observations). Just over half of the male immigrants were classified as refugee immigrants (3,665 individuals).

We classify individuals who are foreign born and who arrived in Sweden after 1968 as immigrants. ${ }^{5}$ Moreover, immigrants who were born in a refugee country, as classified by the Swedish Migration Board at the time of arrival, are defined as refugee immigrants. ${ }^{6}$ It should be noted that all immigrant households included in LINDA, including those defined as refugee immigrants in our study, have obtained residence permits. This means, for instance, that asylum seekers who are yet to obtain a residence permit are not included in LINDA.

To construct the IMMD and the RIMMD variables, which measure the proportion of workers that are immigrants and refugee immigrants, respectively, in a given occupation, we use information from each of the waves of LINDA from 1999 to 2007. We have information regarding individuals' occupations at a three-digit level, and we can distinguish between 109 different occupations. For each occupation and year, we divide the number of immigrants working within that occupation by the total number of individuals working in that occupation (details of these 109 occupations are provided in Table A1). Since LINDA is representative of the population, it is likely that this measure of immigrant density reflects the true proportion of immigrants in different occupations.

Table 1 presents descriptive statistics of the sample used in this paper. The evidence indicates that native workers have higher hourly wages; immigrant workers are

\footnotetext{
${ }^{5}$ We have no information on individuals prior to 1968. Thus, we cannot distinguish between Swedish-born individuals and individuals who were born outside Sweden but arrived before 1968.

${ }^{6}$ LINDA does not provide any information regarding actual refugee status. However, by using the countries defined by the Swedish Migration Board as refugee countries (which vary over time), along with information on country of birth as well as time of arrival in Sweden, we can obtain an approximate measure of refugee status.
} 
more concentrated in urban areas and in occupations in which the proportion of immigrants are higher.

In Table 2 we present a description of immigration-based occupational segregation in Sweden using the Duncan segregation index which is calculated separately for each cross-section by

$$
D=0.5 \cdot \sum_{i=1}^{n}\left|\frac{A_{i}}{X}-\frac{B_{i}}{Y}\right|
$$

where $A_{i}$ and $B_{i}$ are the number of native and immigrant males in occupation $i$, respectively, and where $i$ varies from 1 to n (the number of occupations), $X=\sum_{i=1}^{n} A_{i}$ and $Y=\sum_{i=1}^{n} B_{i}$. The measure $D$ ranges between zero (complete integration) and one (complete segregation).

The mean proportion of immigrants to total employment for native males in Sweden has gradually been increasing, from 6.9 percent in 1999 to 9.6 percent in 2007. The same pattern is observed for immigrant workers as well; the mean proportion of immigrants to total employment gradually increasing from 10 percent to 16 percent. These observations suggest that immigrants' participation rates in the Swedish labor market has increased over this period. However, the Duncan segregation index has also been increasing during the same period implying that the labor market ahs also become more segregated.

In Table 3 we present evidence on occupational segregation among refugees. Calculations are again made for each cross-section wave of LINDA from 1999 to 2007. Since the mean proportion of all immigrants to total employment has gradually been 
increasing, it is likely that the mean proportion of refugee immigrants to total employment has followed a similar pattern. Indeed, the entries in Table 3 confirms shows an increase in the mean proportion of refugee immigrants to total employment from 3.0 percent in 1999 to 4.7 percent in 2007 for native male workers, and 6 percent in 1999 to 10.4 percent in 2007 for male refugee workers. The Duncan segregation index is also increasing, suggesting that occupational segregation is also rising among refugee immigrants. As a point of comparison, the magnitudes of the Duncan segregation indices are higher than those reported by Hirsch and Macpherson (2004) for white and black male workers in the United States.

In Tables 4 and 5 we present average wages across occupations that differ in terms of immigrant and refugee densities. We divide occupations into three categories based on the proportion of immigrant (refugee immigrant) workers in an occupation: occupations with less than nine percent immigrant (refugee immigrant) workers; occupations with nine to 16 percent immigrant (refugee immigrant) workers; and finally occupations with more than 16 percent immigrant (refugee immigrant) workers. For all immigrant groups, average wages are higher in occupations with low fractions of immigrant or refugee workers. In contrast, average wages are considerably lower in occupations with a high proportion of immigrant or refugee.

In Tables 6 and 7, we present similar wage information with the difference that immigrant density now reflects the proportion of immigrants that arrived after 1995 to total employment. Similarly, refugee density is calculated based on the proportion of refugee immigrants that arrived after 1995 to total employment. 
Occupations are again divided into three categories based on the proportion of these relatively new immigrant or refugee workers in an occupation: occupations with less than four percent new immigrant (refugee immigrant) workers; occupations with four to nine percent immigrant (refugee immigrant) workers; and occupations with more than nine percent immigrant (refugee immigrant) workers. The entries in Table 6 shows that average wages for native workers are significantly higher in occupations with a high proportion of recent immigrants. The same is true for immigrant workers. A possible explanation for this observation is that these occupations include high-skilled jobs, such as professors at universities or computer experts in IT firms. Moreover, average wages for refugee workers are essentially the same in all three categories of occupations.

When considering occupational categories based on proportion of new refugee workers, the earning pattern is reversed. Here, average wages are highest for all groups in occupations with low densities of new refugee workers and lowest in occupations with high densities.

\section{Empirical results}

Regression results from ordinary least squares and the fixed effects model are presented in Tables 8 and 9, respectively. The dependent variable is the logarithm of hourly wages and the explanatory variables used are age, age squared, number of children, marital status (e.g. single, married), highest educational attainment (e.g. high school, university), area of residence (e.g. urban area, rural area), years since arrival, years since arrival squared, and the immigrant density variables IMMD and RIMMD. 
In addition to these observed and individual-specific characteristics we include average values of these characteristics by occupation. As mentioned above, these averages are included in an attempt to control for omitted occupational wage determinants. Finally, yearly time dummies and nine occupational variables (i.e. based on the first digit of the 3-digit code of the occupational codes in Table A1) are also included.

We limit our presentation and discussion to the estimated coefficients of the density variables and the entries in Tables 8 and 9 show the effects of the density on log wages for four groups of workers; (1) immigrants, (2) refugee immigrants, (3) new immigrants, and (4) new refugee immigrant workers. ${ }^{7}$

Estimates of the relationship between wages and the density variable $I M M D$ are sensitive to the choice of estimation strategy across demographic groups. For example, the OLS estimate of the effect of IMMD on native wages is -0.386 which yields an elasticity of $-0.031 .^{8}$ Thus, a ten percent increase in the proportion of immigrants in an occupation is predicted to reduce natives' wages with around 0.3 percent. This effect is statistically significant. For all immigrants, regardless of source country, the wage elasticity is almost twice as high, -0.057 , while for the group consisting of refugee immigrants only, the effect is -0.046 . These findings are interesting given that the proportion of immigrant workers to total employment increased significantly during the time period considered in this paper.

The relationship between wages and the density of refugee immigrants, represented by the variable RIMMD, are also presented in Table 8 . The estimated wage

\footnotetext{
${ }^{7}$ The remaining estimates are available upon request.

8 The elasticity is obtained, given the empirical specification, by multiplying the estimated coefficient $(-0.386)$ with the average value of IMMD $(0.08)$.
} 
penalties associated $R I M M D$ are similar to the wage penalties associated with $I M M D$. For natives, the elasticity is -0.032 while it is -0.060 for all immigrants and -0.051 for refugee immigrants.

The final set of results presented in Table 8 show the wage effects from occupational changes in the proportion of recent immigrants. Although the magnitudes of the estimates are comparable and sometimes larger in (absolute value) than the estimates for immigrant densities using all immigrants, the corresponding elasticities are smaller than those reported above. For natives, the elasticity is -0.001 for IMMD and -0.008 for RIMMD. For all immigrants, the elasticity is -0.011 for $I M M D$ and -0.015 for RIMMD while for refugee immigrants, the elasticities are -0.011 and -0.025 for IMMD and RIMMD, respectively. Thus, there is no evidence that the wage penalty associated with increased concentration of immigrants is higher when the measure represents recent immigrants.

A major concern with the OLS results is the possibility that occupational choices are endogenously determined (i.e. those with high levels of unobserved labor market skills are also those who are most likely to choose high wage occupations). As is well known, presence of endogenous variables may seriously invalidate OLS regression coefficients. To address this issue, we utilize the longitudinal nature of the data and include individual-specific intercepts in the regression equation. This approach yields consistent estimates even if occupational choices are endogenous, assuming that these choices are only related to time-invariant and idiosyncratic effects (which are controlled for in this framework) but not to time-varying wage shocks. 
These fixed-effects estimates are presented in Table 9. For all immigrant groups and for all measures of immigrant density, with one exception, the estimated wage penalties are significantly lower when the idiosyncratic and time-invariant effects are removed from the regression equation. For example, the wage elasticities for IMMD are 0.012 for natives, -0.011 for all immigrants, and -0.016 for refugee immigrants. These figures are substantially smaller than those obtained using OLS reported above. This finding suggests that a large extent of the partial correlation, obtained by OLS, between wages and occupational concentration of immigrants is due to time-invariant, idiosyncratic characteristics of individuals. Consequently, these findings suggest that wage differences across occupations with different densities of immigrants are mainly due to quality sorting and to a lesser extent due to the existence of discrimination.

The regression coefficients associated with working in jobs with high refugee densities are uniformly higher than those describing the wage penalty for working in jobs with high immigrant densities. This finding holds across all subgroups. However, the associated wage elasticities are roughly similar for both measures of immigrant density. The elasticities are -0.011 for native workers, -0.012 for immigrant workers, and -0.017 for refugee immigrant workers. The corresponding wage elasticities obtained from the OLS estimates are -0.032 for natives, -0.060 for all immigrants and -0.051 for refugee immigrants. Thus, again the findings indicate that much of the observed wage differences across occupations with different concentrations of immigrants are mainly due to differences in unobserved (in the data) characteristics and to a lesser extent due to the existence of discrimination. 
Regarding the wage effects from occupational changes in the proportion of recent immigrants, the fixed effects results presented in Table 9 are consistent with the OLS findings reported. Indeed, the magnitudes of the elasticities are even smaller than those obtained using OLS estimates. Consequently, there is little evidence suggesting that the wage penalty associated with increased concentration of immigrants is higher when the measure represents recent immigrants.

Wage penalties on workers across demographic subgroups, evident from the results of our fixed effects model, illustrate that changes in any of the four densities we have considered cause refugee workers to suffer the most while the penalties are similar for natives and all immigrants. The estimated penalties associated with changes in immigrant density, modest as they are, imply that the negative relationship between wages and the proportion of immigrant workers in an occupation is almost entirely accounted for by measured and unmeasured worker skills. However, the results in Table 9 indicate that there exists an effect of refugee immigrant composition on wages after accounting for worker heterogeneity. Discrimination may not be the driving force behind the negative correlation between wages and refugee density, but based on our results, it is not possible to completely rule it out.

Finally, analysis at finer levels of aggregation reveals some heterogeneity in the wage penalty for natives across subgroups. Depicting results from the fixed effects model, Table 10 illustrates how native workers with different educational attainment are affected differently by changes in immigrant worker density. Workers with higher educational attainment face higher penalties for working in jobs with higher immigrant density, relative to co-workers in jobs with lower immigrant density. These penalties, 
however, are meager, albeit statistically significant. For example, the wage elasticity associated with a one percent increase in the density of refugee workers in their occupations is -0.014 , somewhat larger than the effect obtained above that did not condition on educational attainment. ${ }^{11}$ Native workers that graduated from high school, or had not completed high school, face wage penalties that are lower and comparable in magnitudes to those reported above for the whole sample of natives.

\section{Conclusions}

This paper attempts to explain the negative relationship between immigrant composition of occupations and wages in Sweden. While there exist a number of studies devoted to the analysis of occupational gender segregation and its impact on the wage structure, there is little, if any, empirical evidence on occupational immigrant segregation. To purge our results from observed and unobserved worker characteristics, we take advantage of a unique longitudinal data source and apply fixed-effects regression techniques on these data. This strategy allows, under certain assumptions, for endogenous sorting into different jobs based on observed and unobserved skills. Occupational immigrant segregation is measured by analyzing the proportion of immigrants in 109 different occupations.

The effect of occupational segregation by immigration status is reduced sharply when endogeneity of occupational attainment is controlled for by using the fixed effects model. Estimated coefficients of our variable of interest, $I M M D$, from the fixed effects model (as well as the OLS estimates) are uniformly negative and comparatively much

\footnotetext{
${ }^{11}$ The elasticity was calculated using the information in Table A2 in appendix.
} 
smaller. An increase in immigrant density penalises refugee workers the most, with each 10 percent increase in IMMD associated with a 0.16 percent reduction in wages. The estimated wage effects are similar when refugee density of occupations is considered instead. Furthermore, when we investigate the relationship between wages and new immigrant composition or new refugee immigrant composition of occupations, we find that the wage penalties are even smaller.

Overall, our results suggest that the negative relationship between wages and the proportion of immigrant workers in an occupation, observed in data, is almost entirely accounted for by measured and unmeasured worker skills. Consequently, these findings suggest that wage differences across occupations with different densities of immigrants are mainly due to quality sorting and to a lesser extent due to the existence of discrimination.

Finally, our results suggest that a combination of strong efforts at enhancing training for immigrants, and particularly refugee immigrants, employer awareness programs and incentives for hiring immigrant workers, among other measures, may prove helpful to improve the state of immigration-based employment and wage differentials in Sweden. 


\section{References}

Baker, M, Benjamin D (1994) The performance of immigrants in the Canadian labour market. Journal of Labour Economics 12(3): 369-405

Baker, M, Fortin N (2001) Occupational gender composition and wages in Canada: 19871988. Canadian Journal of Economics 34(2): 345-376

Bloom, DE, Grenier G, Gunderson M (1995) The changing labour market position of Canadian immigrants. Canadian Journal of Economics 28(4): 987-1005

Borjas, G (1985) Integration, changes in cohort quality, and the earnings of immigrants. Journal of Labor Economics 3(4): 463-489

Borjas G. (1989) Immigrant and emigrant earnings: A longitudinal study. Economic Enquiry 27: 21-37

Chiswick, BR (1978) The effects of Americanization on the earnings of foreign-born men. Journal of Political Economy 86: 897-921

Chiswick, BR (1980) An analysis of the economic progress and impact of immigrants. National Technical Information Service, No. PB80-200454. Report prepared for the Employment and Training Administration, U.S. Department of Labor

Edin, PA, Fredriksson P (2000) LINDA - Longitudinal Individual Data for Sweden. Working Paper 19, Uppsala University.

Edin, PA, LaLonde RJ, Åslund O (2000) Emigration of immigrants and measures of immigrant assimilation. Swedish Economic Policy Review 7: 163-204

Ekberg, J (1990) Invandrarna på arbetsmarknaden (Immigrants in the labour market). Ds 1990: 35, Allmänna Förlaget, Stockholm

Ekberg, J (1994) Economic progress among immigrants in Sweden. Scandinavian Journal of Social Welfare 3: 148-157

Green, DA (1995) Intended and actual occupations of immigrants. In: DeVoretz DJ (eds) Diminishing returns: the economics of Canada's recent immigration policy, CD Howe Institute, Toronto and The Laurier Institution, Vancouver, pp 331-365

Hammar, T (1985) European immigration policy: A comparative study. Cambridge University Press, Cambridge

Hirsch, B, Schumacher E (1992) Labour earnings, discrimination, and the racial composition of jobs. Journal of Human Resources 27: 602-28 
Hirsch, B, Macpherson D (2004) Wages, sorting on skill, and the racial composition of Jobs. Journal of Labour Economics 22(1): 189-210

Piore, MJ (1979) Birds of passage: migrant labour and industrial societies. Cambridge University Press, Cambridge

Zimmermann, KF 1994 The labour market impact of immigration. In Spencer S (eds) Immigration as an economic asset: the German experience. IPPR/Trentham Books, Stoke-on-Trent, pp 39-64 
Table 1

Descriptive statistics

\begin{tabular}{|c|c|c|c|}
\hline & Natives & $\begin{array}{c}\text { All } \\
\text { immigrants }\end{array}$ & $\begin{array}{c}\text { Refugee } \\
\text { immigrants }\end{array}$ \\
\hline Variable & $\begin{array}{l}\text { Mean } \\
\text { (Std.) }\end{array}$ & $\begin{array}{l}\text { Mean } \\
\text { (Std.) }\end{array}$ & $\begin{array}{l}\text { Mean } \\
\text { (Std.) }\end{array}$ \\
\hline Wage (SEK 2006) & $\begin{array}{l}161.77 \\
(76.39)\end{array}$ & $\begin{array}{l}142.95 \\
(66.53)\end{array}$ & $\begin{array}{l}130.56 \\
(48.60)\end{array}$ \\
\hline Age & $\begin{array}{c}42.67 \\
(11.12)\end{array}$ & $\begin{array}{c}41.86 \\
(10.00)\end{array}$ & $\begin{array}{l}40.66 \\
(9.62)\end{array}$ \\
\hline Years since arrival & --- & $\begin{array}{l}16.95 \\
(10.05)\end{array}$ & $\begin{array}{l}14.23 \\
(7.81)\end{array}$ \\
\hline Number of children & $\begin{array}{l}0.73 \\
(1.03)\end{array}$ & $\begin{array}{c}0.87 \\
(1.13)\end{array}$ & $\begin{array}{l}1.00 \\
(1.17)\end{array}$ \\
\hline Single & 0.40 & 0.37 & 0.33 \\
\hline High School & 0.68 & 0.60 & 0.63 \\
\hline College/University & 0.16 & 0.18 & 0.16 \\
\hline Larger cities & 0.41 & 0.28 & 0.28 \\
\hline Urban Area & 0.32 & 0.54 & 0.56 \\
\hline Immigrant Density & 0.08 & 0.14 & 0.15 \\
\hline Refugee Density & 0.04 & 0.07 & 0.09 \\
\hline $\begin{array}{l}\text { Immigrant Density } \\
\text { 1996-2007 }\end{array}$ & 0.01 & 0.03 & 0.03 \\
\hline $\begin{array}{l}\text { Refugee Density 1996- } \\
2007\end{array}$ & 0.006 & 0.01 & 0.02 \\
\hline Number of individuals & 61,540 & 6,883 & 3,665 \\
\hline Number of observations & 381,470 & 36,668 & 19,156 \\
\hline
\end{tabular}


Table 2

Immigrant Composition and Occupational Segregation, 1999-2007

\begin{tabular}{lccccc}
\hline \multicolumn{5}{c}{ Sample Size } & \multicolumn{2}{l}{ Means of Immigrant Density } & Duncan Index \\
\hline \multicolumn{7}{c}{ Year } & Immigrants & Natives & Immigrants & Natives & \\
\hline & & & & & \\
1999 & 3,401 & 42,543 & 0.104 & 0.069 & 0.288 \\
2000 & 3,769 & 43,212 & 0.110 & 0.074 & 0.285 \\
2001 & 4,070 & 44,235 & 0.127 & 0.078 & 0.310 \\
2002 & 4,288 & 44,387 & 0.134 & 0.081 & 0.321 \\
2003 & 4,421 & 45,103 & 0.138 & 0.081 & 0.342 \\
2004 & 4,398 & 43,843 & 0.140 & 0.082 & 0.340 \\
2005 & 4,649 & 43,204 & 0.146 & 0.087 & 0.328 \\
2006 & 4,863 & 43,390 & 0.151 & 0.091 & 0.328 \\
2007 & 5,416 & 44,377 & 0.161 & 0.096 & 0.332 \\
& & & & & \\
\hline
\end{tabular}

Note: Calculations are made from each cross-section of LINDA from 1999 to 2007. Immigrant density measures the proportion of immigrants to total employment in worker's detailed occupation. The Duncan segregation index is calculated separately for each cross-section as $D=0.5 \cdot \sum_{i=1}^{n}\left|\frac{A_{i}}{X}-\frac{B_{i}}{Y}\right|$, where $A_{i}$ and $B_{i}$ are the number of native males and immigrant males in occupation $i$, respectively, where $i$ varies from 1 to n (the number of occupations), $X=\sum_{i=1}^{n} A_{i}$ and $Y=\sum_{i=1}^{n} B_{i}$. It ranges between zero (complete integration) and one (complete segregation). 
Table 3

Refugee Immigrant Composition and Occupational Segregation, 1999-2007.

\begin{tabular}{lccccc}
\hline \multicolumn{5}{c}{ Sample Size } & \multicolumn{2}{l}{ Means of Refugee Density } & Duncan Index \\
\hline Year & $\begin{array}{c}\text { Refugee } \\
\text { Immigrants }\end{array}$ & Natives & $\begin{array}{c}\text { Refugee } \\
\text { Immigrants }\end{array}$ & Natives & \\
\hline 1999 & 1,673 & 42,543 & 0.061 & 0.030 & 0.392 \\
2000 & 1,895 & 43,212 & 0.066 & 0.034 & 0.393 \\
2001 & 2,117 & 44,235 & 0.082 & 0.037 & 0.419 \\
2002 & 2,224 & 44,387 & 0.086 & 0.038 & 0.424 \\
2003 & 2,300 & 45,103 & 0.090 & 0.038 & 0.450 \\
2004 & 2,303 & 43,843 & 0.089 & 0.039 & 0.441 \\
2005 & 2,460 & 43,204 & 0.093 & 0.042 & 0.432 \\
2006 & 2,619 & 43,390 & 0.096 & 0.044 & 0.423 \\
2007 & 2,929 & 44,377 & 0.104 & 0.047 & 0,427 \\
& & & & & \\
\hline
\end{tabular}

Note: See Table 2. 


\section{Table 4}

Average wages by Immigrant Density

\begin{tabular}{|c|c|c|c|}
\hline & \multicolumn{3}{|c|}{ Immigrant Density } \\
\hline & $0-0.09$ & $0.09-0.16$ & $0.16+$ \\
\hline & \multicolumn{3}{|c|}{ Natives } \\
\hline Wage (SEK 2006) & 171.22 & 139.11 & 140.11 \\
\hline \multirow[t]{2}{*}{ N } & 270,966 & 80,589 & 40,316 \\
\hline & \multicolumn{3}{|c|}{ All immigrants } \\
\hline Wage (SEK 2006) & 159.71 & 133.01 & 129.59 \\
\hline \multirow[t]{2}{*}{$\mathrm{N}$} & 15,034 & 11,183 & 12,845 \\
\hline & \multicolumn{3}{|c|}{ Refugee immigrants } \\
\hline Wage (SEK 2006) & 141.45 & 127.12 & 122.42 \\
\hline $\mathrm{N}$ & 6,185 & 6,148 & 8,082 \\
\hline
\end{tabular}

Note: Calculations are made from repeated cross-sections of LINDA 1999 to 2007.

\section{Table 5}

Average wages by Refugee Immigrant Density

\begin{tabular}{|c|c|c|c|}
\hline & \multicolumn{3}{|c|}{ Refugee Immigrant Density } \\
\hline & $0-0.09$ & $0.09-0.16$ & $0.16+$ \\
\hline & \multicolumn{3}{|c|}{ Natives } \\
\hline Wage (SEK 2006) & 164.95 & 134.32 & 120.47 \\
\hline \multirow[t]{2}{*}{ N } & 348,799 & 38,418 & 4,654 \\
\hline & \multicolumn{3}{|c|}{ All immigrants } \\
\hline Wage (SEK 2006) & 151.20 & 128.13 & 111.91 \\
\hline \multirow[t]{2}{*}{$\mathrm{N}$} & 26,000 & 9,870 & 3,192 \\
\hline & \multicolumn{3}{|c|}{ Refugee immigrants } \\
\hline Wage (SEK 2006) & 136.92 & 122.53 & 111.15 \\
\hline $\mathrm{N}$ & 11,832 & 6,305 & 2,278 \\
\hline
\end{tabular}

Note: See Table 4. 


\section{Table 6}

Average wages by occupational density of new immigrants (arrived after 1995)

\begin{tabular}{lccc}
\hline & \multicolumn{3}{c}{ Immigrant Density } \\
\hline & $0-0.04$ & $0.04-0.09$ & $0.09+$ \\
& \multicolumn{3}{c}{ Natives } \\
Wage (SEK 2006) & 161.50 & 152.13 & 199.59 \\
$\mathrm{~N}$ & 362,920 & 23,974 & 4,977 \\
& \multicolumn{3}{c}{ All immigrants } \\
Wage (SEK 2006) & 142.80 & 135.79 \\
$\mathrm{~N}$ & 30,104 & 6,089 & 148.97 \\
& \multicolumn{3}{c}{ Refugee immigrants } \\
Wage (SEK 2006) & 129.69 & 129.56 \\
$\mathrm{~N}$ & 15,038 & 3,671 & 128.90 \\
& & & 1,706 \\
\hline
\end{tabular}

Note: See Table 4.

\section{Table 7}

Average wages by occupational density of new refugee immigrants (arrived after 1995)

\begin{tabular}{lccc}
\hline & \multicolumn{3}{c}{ Refugee Immigrant Density } \\
\hline & $0-0.04$ & $0.04-0.09$ & $0.09+$ \\
& \multicolumn{3}{c}{ Natives } \\
Wage (SEK 2006) & 161.96 & 125.28 & 122.64 \\
$\mathrm{~N}$ & 386,056 & 5,324 & 491 \\
& \multicolumn{3}{c}{ All immigrants } \\
\cline { 2 - 4 } Wage (SEK 2006) & 145.01 & 112.51 & 110.00 \\
$\mathrm{~N}$ & 35,678 & 2,844 & 540 \\
& \multicolumn{3}{c}{ Refugee immigrants } \\
Wage (SEK 2006) & 132.10 & 111.11 \\
$\mathrm{~N}$ & 18,055 & 1,960 & 407.51 \\
& \multicolumn{3}{c}{} \\
\cline { 2 - 4 } & &
\end{tabular}

Note: See Table 4. 
Table 8

OLS regression results, by immigration status

\begin{tabular}{|c|c|c|c|c|}
\hline & $\begin{array}{l}\text { Coefficient } \\
\text { (Std. Err.) }\end{array}$ & $\begin{array}{l}\text { Coefficient } \\
\text { (Std. Err.) }\end{array}$ & $\begin{array}{l}\text { Coefficient } \\
\text { (Std. Err.) }\end{array}$ & $\begin{array}{l}\text { Coefficient } \\
\text { (Std. Err.) }\end{array}$ \\
\hline & \multicolumn{4}{|c|}{ Natives } \\
\hline Immigrant density & $\begin{array}{c}-0.386^{\star \star \star} \\
(0.016)\end{array}$ & --- & --- & --- \\
\hline Refugee density & --- & $\begin{array}{c}-0.792^{\star \star \star} \\
(0.022)\end{array}$ & --- & --- \\
\hline Immigrant Density 1996-2007 & --- & --- & $\begin{array}{c}-0.143^{\star * *} \\
(0.050)\end{array}$ & --- \\
\hline \multirow[t]{2}{*}{ Refugee Density 1996-2007 } & --- & --- & --- & $\begin{array}{c}-1.270^{\star \star \star} \\
(0.066)\end{array}$ \\
\hline & \multicolumn{4}{|c|}{ All immigrants } \\
\hline Immigrant density & $\begin{array}{c}-0.436^{\star \star \star} \\
(0.036)\end{array}$ & --- & --- & --- \\
\hline Refugee density & --- & $\begin{array}{c}-0.858^{\star \star \star} \\
(0.047)\end{array}$ & --- & --- \\
\hline Immigrant Density 1996-2007 & --- & --- & $\begin{array}{c}-0.377^{\star \star \star} \\
(0.083)\end{array}$ & --- \\
\hline \multirow[t]{2}{*}{ Refugee Density 1996-2007 } & --- & --- & --- & $\begin{array}{c}-1.540^{\star * *} \\
(0.157)\end{array}$ \\
\hline & \multicolumn{4}{|c|}{ Refugee immigrants } \\
\hline Immigrant density & $\begin{array}{c}-0.309 \star \star \star \\
(0.043)\end{array}$ & --- & --- & --- \\
\hline Refugee density & --- & $\begin{array}{c}-0.570^{\star \star \star} \\
(0.055)\end{array}$ & --- & --- \\
\hline Immigrant Density 1996-2007 & --- & --- & $\begin{array}{c}-0.381^{\star \star \star} \\
(0.089)\end{array}$ & --- \\
\hline Refugee Density 1996-2007 & --- & --- & --- & $\begin{array}{c}-1.254^{\star \star \star} \\
(0.176)\end{array}$ \\
\hline
\end{tabular}

Note: ${ }^{*},{ }^{* *},{ }^{* *}$ denote significance at the 10,5 and 1 percent levels, respectively. Dependent variable is log of hourly wages. Explanatory variables included are age, age squared, number of children, marital status, highest educational attainment, area of living, years since arrival, years since arrival squared, and the immigrant density. Coefficient of the density variable is shown. Robust standard errors in parentheses. Occupation means of the X's are included in the estimation in order to control for omitted occupational wage determinants, as well as yearly time dummies, plus nine occupational variables. 
Table 9

Fixed effects regression results, by immigration status

\begin{tabular}{|c|c|c|c|c|}
\hline & $\begin{array}{l}\text { Coefficient } \\
\text { (Std. Err.) }\end{array}$ & $\begin{array}{l}\text { Coefficient } \\
\text { (Std. Err.) }\end{array}$ & $\begin{array}{l}\text { Coefficient } \\
\text { (Std. Err.) }\end{array}$ & $\begin{array}{l}\text { Coefficient } \\
\text { (Std. Err.) }\end{array}$ \\
\hline & \multicolumn{4}{|c|}{ Natives } \\
\hline Immigrant density & $\begin{array}{c}-0.146 * \star \star \\
(0.010)\end{array}$ & --- & --- & --- \\
\hline Refugee density & --- & $\begin{array}{c}-0.275^{\star \star \star} \\
(0.014)\end{array}$ & --- & --- \\
\hline Immigrant Density 1996-2007 & --- & --- & $\begin{array}{c}-0.263^{\star \star \star} \\
(0.027)\end{array}$ & --- \\
\hline \multirow[t]{2}{*}{ Refugee Density 1996-2007 } & --- & --- & --- & $\begin{array}{c}-0.787^{\star \star \star} \\
(0.045)\end{array}$ \\
\hline & \multicolumn{4}{|c|}{ All immigrants } \\
\hline Immigrant Density & $\begin{array}{c}-0.079 * \star \star \\
(0.024)\end{array}$ & --- & --- & --- \\
\hline Refugee density & --- & $\begin{array}{c}-0.176^{\star \star \star} \\
(0.031)\end{array}$ & --- & --- \\
\hline Immigrant Density 1996-2007 & --- & --- & $\begin{array}{l}-0.057 \\
(0.058)\end{array}$ & --- \\
\hline \multirow[t]{2}{*}{ Refugee Density 1996-2007 } & --- & --- & --- & $\begin{array}{c}-0.431^{\star \star *} \\
(0.079)\end{array}$ \\
\hline & \multicolumn{4}{|c|}{ Refugee immigrants } \\
\hline Immigrant Density & $\begin{array}{c}-0.108^{\star \star \star} \\
(0.031)\end{array}$ & --- & --- & --- \\
\hline Refugee density & --- & $\begin{array}{c}-0.188 \star \star \star \\
(0.038)\end{array}$ & --- & --- \\
\hline Immigrant Density 1996-2007 & --- & --- & $\begin{array}{l}-0.118 \\
(0.072)\end{array}$ & --- \\
\hline Refugee Density 1996-2007 & --- & --- & --- & $\begin{array}{c}-0.473^{\star \star *} \\
(0.100)\end{array}$ \\
\hline
\end{tabular}

Note: See Table 8. 


\section{Table 10}

Fixed effects regression results for natives, by education.

\begin{tabular}{|c|c|c|c|c|}
\hline & $\begin{array}{l}\text { Coefficient } \\
\text { (Std. Err.) }\end{array}$ & $\begin{array}{l}\text { Coefficient } \\
\text { (Std. Err.) }\end{array}$ & $\begin{array}{l}\text { Coefficient } \\
\text { (Std. Err.) }\end{array}$ & $\begin{array}{l}\text { Coefficient } \\
\text { (Std. Err.) }\end{array}$ \\
\hline & \multicolumn{4}{|c|}{ University degree } \\
\hline Immigrant density & $\begin{array}{c}-0.156^{\star \star \star} \\
(0.042)\end{array}$ & --- & --- & --- \\
\hline Refugee density & --- & $\begin{array}{c}-0.465^{\star \star \star} \\
(0.065)\end{array}$ & --- & --- \\
\hline Immigrant Density 1996-2007 & --- & --- & $\begin{array}{l}0.157^{\star *} \\
(0.065)\end{array}$ & --- \\
\hline \multirow[t]{2}{*}{ Refugee Density 1996-2007 } & --- & --- & -- & $\begin{array}{l}-0.343^{\star} \\
(0.207)\end{array}$ \\
\hline & \multicolumn{4}{|c|}{ High school degree } \\
\hline Immigrant Density & $\begin{array}{c}-0.130^{\star \star \star} \\
(0.012)\end{array}$ & --- & --- & --- \\
\hline Refugee density & --- & $\begin{array}{c}-0.235^{\star \star \star} \\
(0.017)\end{array}$ & --- & --- \\
\hline Immigrant Density 1996-2007 & --- & --- & $\begin{array}{c}-0.380^{\star \star \star} \\
(0.031)\end{array}$ & --- \\
\hline \multirow[t]{2}{*}{ Refugee Density 1996-2007 } & --- & --- & --- & $\begin{array}{c}-0.775^{\star \star \star} \\
(0.055)\end{array}$ \\
\hline & \multicolumn{4}{|c|}{ Less than high school } \\
\hline Immigrant Density & $\begin{array}{c}-0.101^{\star * \star} \\
(0.018)\end{array}$ & --- & --- & --- \\
\hline Refugee density & --- & $\begin{array}{c}-0.168^{\star \star \star} \\
(0.025)\end{array}$ & --- & --- \\
\hline Immigrant Density 1996-2007 & --- & --- & $\begin{array}{c}-0.275^{\star \star \star *} \\
(0.048)\end{array}$ & --- \\
\hline Refugee Density 1996-2007 & --- & --- & --- & $\begin{array}{c}-0.431^{\star \star \star} \\
(0.071)\end{array}$ \\
\hline
\end{tabular}

Note: See Table 8. 


\section{Appendix}

\section{Table A1}

Swedish standard classification of occupations (3-digit level)

No. Occupation

111 Legislators and senior government officials

112 Senior officials of special-interest organisations

121 Directors and chief executives

122 Production and operations managers

123 Other specialist managers

$131 \quad$ Managers of small enterprises

211 Physicists, chemists and related professionals

212 Mathematicians and statisticians

213 Computing professionals

214 Architects, engineers and related professionals

221 Life science professionals

222 Health professionals (except nursing)

223 Nursing and midwifery professionals

231 College, university and higher education teaching professionals

232 Secondary education teaching professionals

233 Primary education teaching professionals

234 Special education teaching professionals

235 Other teaching professionals

241 Business professionals

242 Legal professionals

243 Archivists, librarians and related information professionals

244 Social science and linguistics professionals (except social work professionals)

245 Writers and creative or performing artists

246 Religious professionals

247 Public service administrative professionals

248 Administrative professionals of special-interest organisations

249 Psychologists, social work and related professionals

311 Physical and engineering science technicians

312 Computer associate professionals

313 Optical and electronic equipment operators

314 Ship and aircraft controllers and technicians

315 Safety and quality inspectors

321 Agronomy and forestry technicians

322 Health associate professionals (except nursing)

323 Nursing associate professionals

324 Life science technicians

331 Pre-primary education teaching associate professionals

332 Other teaching associate professionals 
Table A1 continued

No. Occupation

$341 \quad$ Finance and sales associate professionals

342 Business services agents and trade brokers

343 Administrative associate professionals

344 Customs, tax and related government associate professionals

345 Police officers and detectives

346 Social work associate professionals

347 Artistic, entertainment and sports associate professionals

348 Religious associate professionals

411 Office secretaries and data entry operators

$412 \quad$ Numerical clerks

$413 \quad$ Stores and transport clerks

414 Library and filing clerks

$415 \quad$ Mail carriers and sorting clerks

419 Other office clerks

$421 \quad$ Cashiers, tellers and related clerks

$422 \quad$ Client information clerks

511 Travel attendants and related workers

512 Housekeeping and restaurant services workers

513 Personal care and related workers

514 Other personal services workers

515 Protective services workers

$521 \quad$ Fashion and other models

522 Shop and stall salespersons and demonstrators

611 Market gardeners and crop growers

613 Crop and animal producers

614 Forestry and related workers

615 Fishery workers, hunters and trappers

711 Miners, shot firers, stonecutters and carvers

712 Building frame and related trades workers

713 Building finishers and related trades workers

714 Painters, building structure cleaners and related trades workers

721 Metal moulders, welders, sheet-metal workers, structural-metal preparers and related trades workers

722 Blacksmiths, tool-makers and related trades workers

723 Machinery mechanics and fitters

724 Electrical and electronic equipment mechanics and fitters

731 Precision workers in metal and related materials

732 Potters, glass-makers and related trades workers

733 Handicraft workers in wood, textile, leather and related materials

734 Craft printing and related trades workers

$741 \quad$ Food processing and related trades workers

742 Wood treaters, cabinet-makers and related trades workers 
Table A1 continued

No. Occupation

743 Garment and related trades workers

744 Pelt, leather and shoemaking trades workers

811 Mineral-processing-plant operators

812 Metal-processing-plant operators

813 Glass, ceramics and related plant operators

815 Chemical-processing-plant operators

816 Power-production and related plant operators

817 Industrial-robot operators

821 Metal- and mineral-products machine operators

822 Chemical-products machine operators

823 Rubber- and plastic-products machine operators

824 Wood-products machine operators

825 Printing-, binding- and paper-products machine operators

826 Textile-, fur- and leather-products machine operators

827 Food and related products machine operators

828 Assemblers

829 Other machine operators and assemblers

831 Locomotive-engine drivers and related worker

832 Motor-vehicle drivers

833 Agricultural and other mobile-plant operators

834 Ships' deck crews and related workers

911 Street vendors and market salespersons

912 Helpers and cleaners

913 Helpers in restaurants

914 Doorkeepers, newspaper and package deliverers and related workers

915 Garbage collectors and related labourers

919 Other sales and services elementary occupations

921 Agricultural, fishery and related labourers

931 Mining and construction labourers

932 Manufacturing labourers

933 Transport labourers and freight handlers

011 Armed forces 


\section{Table A2}

Immigrant densities for natives, by highest educational attainment.

\begin{tabular}{lccc}
\hline & $\begin{array}{c}\text { University } \\
\text { degree }\end{array}$ & $\begin{array}{c}\text { High school } \\
\text { degree }\end{array}$ & $\begin{array}{c}\text { Less than } \\
\text { high school }\end{array}$ \\
\hline Variable & Mean & Mean & Mean \\
\hline & & & \\
Immigrant Density & 0.077 & 0.080 & 0.094 \\
$\begin{array}{l}\text { Refugee Density } \\
\text { Immigrant Density 1996- }\end{array}$ & 0.030 & 0.039 & 0.048 \\
$\begin{array}{l}\text { 2007 } \\
\text { Refugee Density 1996- }\end{array}$ & 0.020 & 0.014 & 0.015 \\
2007 & 0.004 & 0.006 & 0.008 \\
& & & \\
\hline
\end{tabular}

